Original Research Paper

\title{
Ekstrak Cair dan Padat Lombok Sargassum aquifolium Merangsang Pertumbuhan dan Hasil Tanaman Mentimun (Cucumis sativus L.)
}

\author{
Eka S. Prasedya', Sonia A. Pebriani ${ }^{2}$, Yogi Ambana ${ }^{3}$, Anggit LS ${ }^{4}$, Sri Widyastuti ${ }^{5}$, Aluh Nikmatullah ${ }^{6}$, Haji \\ Sunarpi $^{7 *}$ \\ ${ }^{1,2,7}$ Pusat Unggulan Biosains dan Bioteknologi, FMIPA, Universitas Mataram \\ ${ }^{3}$ Program Studi Biologi, Fakultas Matematika dan Ilmu Pengetahuan Alam, Universitas Mataram \\ ${ }^{4}$ Program Studi Farmasi, Fakultas Kedokteran, Universitas Mataram \\ ${ }^{5}$ Fakultas Teknologi Pangan dan Agroindustri, Universitas Mataram \\ ${ }^{6}$ Fakultas Pertanian, Universitas Mataram
}

\section{Riwayat artikel}

Received : 26 September 2019

Revised : 22 Oktober 2019

Accepted : 24 Oktober 2019

Published : 4 November 2019

*Corresponding Author:

Haji Sunarpi,

Bioscience and Biotechnology

Research Center, FMIPA,

Universitas Mataram J1.

Majapahit No. 62 Mataram-

NTB 83125, Indonesia;

Email: ekajp@yahoo.com
Abstrak: Pemupukan anorganik pada sistem budidaya pertanian menimbulkan beberapa masalah, antara lain biaya produksi meningkat, pendapatan petani menurun, tanah menjadi keras dan tidak subur, serta mencemari lingkungan. Karena itu, perlu ada upaya untuk menemukan sumber bahan baku pupuk yang mudah didapat, murah dn ramah lingkungan. Beberapa peneliti sebelumnya melaporkan bahwa rumput laut mengandung fitohormon dan elemen essensial yang dapat merangsang pertumbuhan dan hasil tanaman. Artikel ini melaporkan pengaruh ekstrak cair dan padat Sargassum aquifolium terhadap pertumbuhan dan hasil tanaman mentimun. Ekstrak cair dan padat alga tersebut diperoleh dengan metode Godlewska et al., 2016. Ekstrak cair (10\%) disemprotkan satu kali seminggu selama pertumbuhan vegetatif. Ekstrak padat (5\%) diberikan pada media tanah saat tanam. Ekstrak cair secara signifikan mempengaruhi sebagian besar parameter pertumbuhan (tinggi tanaman, jumlah cabang dan berat kering tunas) dan pertumbuhan generatif (jumlah dan berat buah per tanaman), namun ekstrak cair tersebut tidak secara signifikan mempengaruhi berat kering akar. Fenomena serupa juga ditemukan pada pengaruh ekstrak padat terhadap pertumbuhan dan hasil tanaman mentimun. Hasil penelitian ini memberikan indikasi bahwa ekstrak cair yang dilaporkan mengandung fitohormon, dan ekstrak padat yang mengandung elemen essensial dapat dikembangkan sebagai "biostimulan" dan "biofertlizer" organik yang dapat memacu pertumbuhan dan produksi tanaman.

Kata kunci: ekstrak cair, ekstrak padat, Sargassum quifolium, pertumbuhan, hasil, tanaman mentimun.

Abstract: Aplication of inorganic fertilizer in agriculture cultivation system causes some disadventages, such as increase cost production, reduce farmer's income and soil fertility, and hqrm our environment. Therefore, it is needed to find out raw materials for fertilizer which easy to obtain, cheap and adaptive to our environment. Previous researchres reported that seaweed contained plant growth hormones and essential elements stimuliting growth and yield of plants. This article reports effect of liquid and solid extracts of Sargassum aquifolium on growth and yield of cucumber plants. Liquid and solid extracts were obtained according to modified Godlewska method (2016). Liquid extract $(10 \%)$ was sprayed once a week during vegetative growth. Moreover, solid extract $(5 \%)$ was applied in plant media. Liquid extract influenced significantly most growth parameters, such as plant height, branch number, shoot dry weight and yield parameters like fruit number and fruit weight per plant, but liquid extract did not significantly affect root dry weight. Similar phenomena was also found on the effect of solid extract on growth and yield of cucumber plants. The results suggest that liquid and solid extracts containg plant growth 
hormones and essential element respectively, could be developed as organic biostimulant and biofertilizer inducing growth and plant production.

Keywords: liquid extract, solid extract, Sargassum quifolium, growth, yield, cucumber plants.

\section{Pendahuluan}

Pertumbuhan anorganik menimbulkan banyak masalah, antara lain meningkatkan biaya produksi, menurunkan pendapatan petani, menyebabkan tanah mengeras dan menurunkan kesuburan tanah, serta mencemari lingkunag. Karena itu, diperlukan adanya pemahaman sumber "biostimulant" dan "biofertilizer" organik, yang mudah didapat, murah dan tidak mencemari lingkunagn. Beberapa peneiti sebelumnya melaporkan rumput laut (macroalgae) mengandung hormon pertumbuhan tanaman (plant growth hormone) dan elemen essensial (macro-micro essential element) yang dapat merangsang pertumbuhan dan hasil tanaman (Zodape et al., 2001; Godlewska et al., 2016).

Atas dasar kandungan tersebut, beberapa peneliti sebelumnya melaporkan esktrak rumput laut mempengaruhi beberapa fase pertumbuhan tanaman, mulai dri fase perkecambahan, pembibitan, pertumbuhan vegetatif dan pertumbuhan generatif. Rangkuman dari beberapa literatur mendokumentasikan bahwa hormon pertumbuhan seperti gibberellin, IAA dan NAA, berperan sebagai induksi signal (transduction signal) untuk memulai kerja enzim katalitik, seperti protease, amilase dan lipase pada biji-bijian yang sedang berkecambah (Raven et al., 1992; Salisbury dan Ross, 1995; Teiz dan Zeiger, 1998; Buchanan et al., 2000).

Mengingat ekstrak cair beberapa spesies rumput laut diketahui mengandung hormone pertumbuhan (Zodapr, 2001), maka pemberian ekstrak cair rumput laut memacu perkecambahan biji beberapa tanaman sayuran (Rao dan Chatterjee, 2014). Selain perkecambahan, pembibitan ekstrak cair rumput laut juga dilaporkan dapat memacu pembibitan tanaman tomat (Hermandez-Herrera, 2013). Hal ini mengindikasikan bahwa fitohormon pada ekstrak cair menginduksi amilasi, proteasi dan lipase untuk meremobilisasi makromolekul cadangan pada koteloden (dikotel) atau endosperm (monokotil) menunju titik tumbuh sebagaimana yang terjadi pada tanaman kedelai (Sunarpi dan Anderson, 1995). Atas dasar argumentasi tersebut, ekstrak cair rumput laut menginduksi pembibitan tanaman Vigna mungo L. (Kalaivanan dan Venkateslu, 2012) dan tanaman tomat (hernandez-Herrera, 2013).

Selain perkecambahan dan pembibitan, para peneliti juga melaporkan pengaruh ekstrak cair terhadap ertumbuhan vegetatif beberapa spesies tanaman. Saat pertumbuhan awal vegetatif, tanaman sudah mulai menyerap nutrisi dari lingkungan sekitarnya, dan mentranslokasi produk fotosintesis dari daun tua ke daun muda. Karena itu, ekstrak cair yang mengandung hormon pertumbuhan dapat memacu serapan unsur hara, fotosintesis dan pertumbuhan. Selain itu, pemberian ekstrak padat yang mengandung elemen essensial di media tanah dapat meningkatkan ketersediaan mineral nutrisi di media tanah, memacu serapan, fotosintesis dan pertumbuhan, sebagaimana didokumentasikan pada literatur (Buchanan et al., 2000). Atas dasar argumentasi ilmiah tersebut, maka pemberian ekstrak cair dan padat rumput laut dapat memacu pertumbuhan beberapa sepesies tanaman, seperti tanaman buncis (Sivasankari et al., 2005), tanaman jagung (Safinaz dan Ragaa, 2013) dan tanaman bunga matahari (Majed et al., 2015).

Selain pengaruh ekstrak cair terhadap perkecambahan, pembibian dan pertumbuhan, ada juga peneliti yang mengamati pengaruh ekstrak cair Hypnea musciformis dan Gracilaria textorii terhadap produktivitas tanaman belinjo, tomat dan lombok (Raoo dan Chatterjee, 2014). Mengingat ekstrak padat diketahui mengandung elemen essensial (Godlewska et al., 2016), maka beberapa pupuk organik yang mengandung ekstrak padat (fellet) rumput laut dapat meningkatkan produksi tanaman sayur-sayuran (Li et al., 2017), tanaman kedelai (Kocira et al., 2018). Selain itu, ekstrak padat alga coklat dilaporkan meningkatkan pertumbuhan dan hasil tanaman padi (Sunarpi et al., 2018). Artikel ini melaporkan pengaruh ekstrak cair dan ekstrak padat Sargassum aquifolium terhadap pertumbuhan dan hasil tanaman mentimun. Hasil penelitian menunjukkan ekstrak cair dan padat Sargassum aquifolium secara signifikan meningkatkan pertumbuhan dan hasil tanaman mentimun. Hal ini mengindikasikan bahwa ekstrak cair Sargassum aquifolium dapat dikembangkan sebagai "biostimulan" yang dapat merangsang pertumbuhan dan hasil tanaman. Selain itu, ekstrak padat alga ini dapat dikembangkan sebagai "biofertilizer" yang diaplikasikan pada media tanah, meningkatkan ketersediaan nutrisi di dalam tanah, memacu serapan mineral, pertumbuhan dan produksi tanaman.

\section{Bahan dan Metode}

\section{Desain percobaan}

Percobaan didesain dengan rancangan acak lengkap di rumah plastik Jatisela Kabupaten Lombok 
Barat pada bulan Juli sampai dengan Oktober 2018. Percobaan terdiri atas tiga perlakuan, masing-masing E0, tidak diperlakuan dengan ekstrak (baik ekstrak cair maupun ekstrak padat) dengan media terdiri atas $7 \mathrm{~kg}$ tanam, 400 gr kotoran ayam, 200 gr sekam padi dan 400 gr serbuk gergaji; LE, $10 \%$ ekstrak cair Sargassum aquifolium dengan media terdiri atas $7 \mathrm{~kg}$ tanam, $400 \mathrm{gr}$ kotoran ayam, 200 gr sekam padi dan 400 gr serbuk gergaji; SE, tidak diperlakukan dengan eksttak cair, dengan media terdiri atas $7 \mathrm{~kg}$ tanam, 400 gr kotoran ayam, 150 gr sekam padi, 400 gr serbuk gergaji dan 50 gr ekstrak padat Sargassum aquifolium. Setiap perlakuan diulang tiga kali, sehingga terdapat sembilan pot perlakuan. Parameter pertumbuhan, seperti tinggi tanaman, jumlah cabang, berat kering tunas (shoot) dan berat kering akar (root) diamati saat panen. Selain itu, parameter hasil, seperti jumah buah dan berat buah per tanaman diamati secara bertahap sejakpemunculannya buah sampai dengan saat panen. Data dianalisis dengan analisis ragam (ANOVA) yang dilanjutkan dengan " $t$ test" pada taraf nyata 5\%. Data diekspresikan dalam bentuk nilai rata-rata (mean) tiga ulangan \pm SD yang diikuti huruf $(\mathrm{a} / \mathrm{b})$ untuk menunjukkan signifikansinya.

\section{Koleksi sampel dan ekstraksi}

Sampel, Sargassum aquifolium, dikolekasi di Teluk Ekas Lombok Timur. Setelah sampel dikoleksi, dibersihkan enggunakan air laut, dikeringkan di tempa yang teduh, tidak terkena matahri selama tiga hari. Setelah kering, sampel dipotong kecil-kecil menggunakan pisau. Potongan sampel $(1 \mathrm{~kg})$ dimasukkan ke dalam $3 \mathrm{~L}$ glas kimia, ditambahkan $3 \mathrm{~L}$ air distilasi, diaduk secara merata selama 30 menit, dan diekstraksi dengan prosedur Godlewska dkk (2016) yang telah dimodifikasi. Setelah itu, campuran homogen ditempatkan pada air mendidih di "water bath" pada suhu 95 $\mathrm{C}$ selama 30 menit. Selanjutnya, campuran disaring dengan kertas saring "whatman no 1" sampai semua campuran terpisahkan antara cairan (ekstran cair) dan padatan (ekstrak padat). Esktrak cair yang didapatkan dengan cara ini dinyatakan sebagai ekstrak cair dengan konsentrasi $100 \%$. Sedangkan ekstrak padat yang didapatkan dapat diaplikasikan ke media tanah dengan komposisi yang sudah ditetapka di atas.

Aanalisis kadar hormon tumbuh pada ekstrak cair menggunakan HPLC

Kadar hormon pertumbuhan pada ekstrak cair Sargassum aquifolium dideteksi menggunakan HPLC sesuai prosedur Godlewska et al., (2016) yang dimodifikasi. Tahap awal, dibuat larutan standard hormon pertumbuhan, seperti IAA (indole acetic acid), NAA (6napthalene acetic acid), GA3 (gibberellic acid), ZA (zeatin), kinetin, ABA (abscisic acid), 2,4-D (2,4 dichlorophenoxyacetic acid), masing-masing dengan konsentrasi $0,1 \%$. Selanjutnya, protokol HPLC dioptimalisasi menggunakan tujuh standard untuk setiap jenis hormon pertumbuhan.

Analisis HPLC telah dilakukan menggunakan "a Shimpact CLC-ODS column" (Shmadzu, Japan). Setelah itu, setiap sampel diinjeksi secara otomatis secara terjadi pengenceran pada kolom HPLC, dipisahkan pada suhu kolom $30^{\circ} \mathrm{C}$, tekanan $50 \mathrm{~kg} / \mathrm{cm}^{2}$, kecepatan retensi 0,5 $\mathrm{mL}$ per menit menggunakan methanol/air distilasi (7:1, v/v) sebagai fase bergerak. Akhirnya, analisis kadar hormon tumbuh dilakukan dengan membandingkan analisis kromotagoram setiap sampel dengan kromatogram standard hormon tumbuh. Data diekspresikan dalam bentuk nilai rata-rata (mean) dua ulangan \pm SD.

Aanalisis kadar elemen essensial pada ekstrak padat menggunakan AAS

Kadar elemen esensial, seperti nirogen, fosfor, kalium, calcium, mangan dan besi, pada ekstrak padat Sargassum aquifolium ditentukan menggunakan AAS (Atomic Absorbance Spectroscophy) sesuai metode Godlewska dkk (2016) yang dimodifiasi. Tahap awal, dipersiapkan larutan standard nitrogen, fosfor, kalium, calcium, mangan dan besi dengan konsentrasi $0,1 \%$. Setelah itu, felet (10 gr) didestruksi menggunakan $100 \mathrm{~mL}$ $\mathrm{HCl}$ pekat pada suhu sekitar $400^{\circ} \mathrm{C}$. Larutan satndard atau larutan sampel diinjesi ke kolom AAS sesuai prosedur baku yang telah ditetapkan. Analisis kadar elemen essensial dilakukan dengan membandingkan luas kromgram sampel dan standard yang ditimbulkan. Data diekspresikan dalam bentuk nilai rata-rata (mean) dua ulangan \pm SD.

\section{Persiapan media tanah, bibit dan penyemrpotan ekstrak}

Media tanah dipersiapkan sesuai perlakuan yang telah ditetapkan. Media E0, terdiri atas $7 \mathrm{~kg}$ tanam, 400 gr kotoran ayam, 200 gr sekam padi dan 400 gr serbuk gergaji; Media LE, terdiri atas $7 \mathrm{~kg}$ tanam, 400 gr kotoran ayam, 200 gr sekam padi dan 400 gr serbuk gergaji; Media SE, terdiri atas $7 \mathrm{~kg}$ tanam, $400 \mathrm{gr}$ kotoran ayam, $150 \mathrm{gr}$ sekam padi, 400 gr serbuk gergaji dan 50 gr ekstrak padat Sargassum aquifolium. Masing-masing campuran diaduk secara homogen, sehingga terdapat campuran media tanah yang homogen untuk masing-masing perlakuan.

Pembibitan diawali dengan menempatkan 50 biji mentimun pada gelas kimia, ditambahkan $100 \mathrm{~mL}$ air distilasi, dan diimbibi selama 2 jam. Setelah itu, air dituang, biji diperam pada kertas towel dan ditempatkan pada tempat gelap sepanjang malam. Biji yang tumbuh dengan menunjukkan adanya radikula, ditanam pada 
media tanah dan pasir dengan perbandingan 3:1. Setelah bibit berumur 14 hari, ditanam 1 bibit per pot, pada media tanah yang telah disiapkan. Setelah bibit berumur 14 hari, dilakukan penyemprotan $10 \%$ ekstrak cair Sargassum aquifolium. Penyemprotan dilakukan selama masa pertumbuhan vegetatif.

\section{Pemupukan dan pemeliharaan}

Selama percobaan ini, tidak dilakukan pemupukan anorganik, cukup mengaplikasikan media padat pada media tanah sesuai perlakuan yang telah ditetapkan. Pemeliharaan selain pemupukan, seperti pengairan dan penggunaan pestisida sesuai dengan prosedur pemeliharaan tanaman pangan dan hortikura yang dikeluarkan oleh Dinas terkait.

\section{Pengamatan parameter dan analisis data}

Parameter pertumbuhan seperti tinggi tanaman dan jumlah cabang diamati saat panen. Sedangkan berat kering tunas (shoot dry weight) dan berat kering akar (root dry weight) diukur setelah sampel dikeringkan selama 3 hari didalam oven pada suhu $60^{\circ} \mathrm{C}$. Parameter hasil seperti jumlah buah dan berat buah per tanaman diamati secara bertahap sejak meunculnya buah sampai panen. Semua data yang terkumpul dianalisis dengan analisis sidik ragam (ANOVA) yang dilanjutkan dengan uji beda nya menggunakan "t-test" pada taraf nyata 5\%. Data diekspresikan dalam bentuk nilai rata-rata (mean) tiga ulangan \pm SD yang diikuti dengan hurup $\mathrm{a} / \mathrm{b} / \mathrm{c}$ untuk menunjukkan nilai signifikansinya.

\section{Hasil dan Pembahasan}

\section{Hasil}

Kromatogram HPLC extrak cair Lombok Sargassum aquifolim dan larutan standard

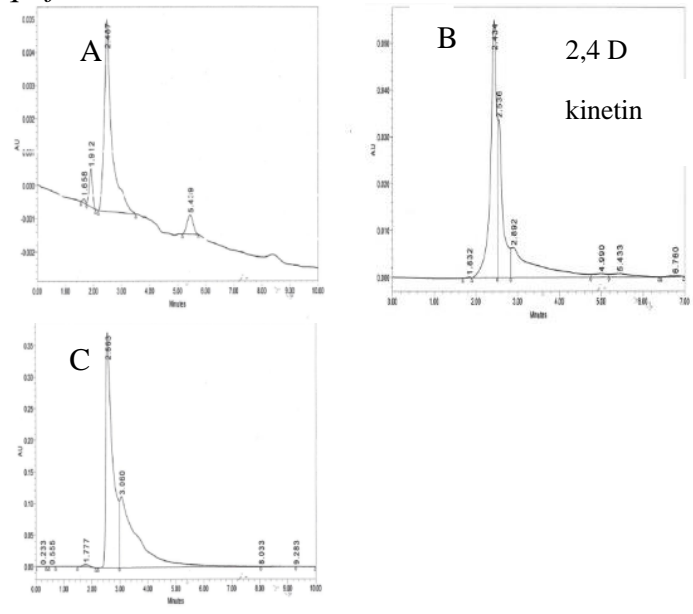

Gambar 1. Hasil analisis HPLC yang menunjukkan puncak spektrum standard 2,4-D (A), puncak spektrum 2,4-D dan kinetin pada ekstrak cair Lombok Sargassum aquifolium (B), puncak spektrum standard kinetin (C).

Hasil analisis HPLC menunjukkan puncak spektrum larutan standar 2,4-D (A), puncak spektrum larutan kinetin (C), dan puncak spektrum 2,4-D dan kinetin pada ekstram cair Sargassum aquifolium (B). Dengan memperhitungkan luas spektrum hormon tumbuh standard, maka konsentrasi 2,4-D dan kinetin pada ekstrak cair Sargassum aquifolium dapat ditentukan. Data pada tabel 1 menunjukkan kadar 2,4-D dan kinetin pada ekstrak cair, masing-masing sebesar 0,508 dan 0,005 mgml $^{-1}$ larutan ekstrak. Kadar 2,4-D, yang merupakan kelompok auksin pada ekstrak cair, cukup menonjol pada ekstrak cair, yang disusul oleh keberaadaan kinetin (Tabel 1).

Tabel 1. Konsentrasi 2,4-D dan kinetin pada ekstrak cair Lombok Sargassum aquifolium yang dianalisis mengguunakan HP:C

\begin{tabular}{|l|c|}
\hline $\begin{array}{l}\text { Plant growth } \\
\text { hormone }\end{array}$ & Concentration $\left(\mathrm{mg} \mathrm{ml}^{-1}\right)$ \\
\hline $2.4 \mathrm{D}$ & $0,508 \pm 0,02$ \\
\hline Kinetin & $0,005 \pm 0.001$ \\
\hline
\end{tabular}

Konsentrasi elemen essensial pada ekstrak padat Sargassum aquifolium

Kadar elemen essensial, seperti N, P, K, Ca, Mn dan Fe pada ekstrak padat Sargassum aquifolium ditunjukkan pada tabel 2. Kadar makro esensial utama, seperti N, P, K dan Ca relatif sama seperti yang ditemukan pada jaringan tanaman pada umumnya (Salisbury dan Ross, 1995 dan Teiz dan Zeiger, 1998). Namun demikian, yang menonjol adi $\mathrm{C}$ kandungan unsur essensial mikro seperti besimdan nıanzan yang masing-masing mencapai 50 dan $8,3 \%$ berat kering ekstrak padat.

Tabel 2. Kadar elemen essensial pada ekstrak padat Sargassum aquifolium

\begin{tabular}{|l|c|}
\hline Elemen Essensial & $\begin{array}{l}\text { Konsentrasi (\% berat } \\
\text { kering) }\end{array}$ \\
\hline $\mathrm{N}$ & $0,48 \pm 0,02$ \\
\hline $\mathrm{P}$ & $0,06 \pm 0.003$ \\
\hline $\mathrm{K}$ & $6,01 \pm 0,31$ \\
\hline $\mathrm{Ca}$ & $0,90 \pm 0,04$ \\
\hline $\mathrm{Fe}$ & $50 \pm 2,3$ \\
\hline $\mathrm{Mn}$ & $8,3 \pm 0,35$ \\
\hline
\end{tabular}


Pengaruh ekstrak cair dan padat Sargassum aquifolium pada pertumbuhan

Ekstrak cair dan ekstrak padat Sargassum aquifolium (ditunjukan pada gambar 2). Pengaruh ekstrak cair Sargasum aquifolium pada pertumbuhan tanaman mentimun, seperti tinggi tanaman (gambar 3), jumlah cabang (gambar 4), berat kering tunas (gambar 5) dan berat kering akar (gambar 6). Data pada gambar 3 menunjukkan bahwa esktrak cair mempengaruhi secara signifikan tinggi tanaman. Tanaman mentimun yang diperlakukan dengan $10 \%$ ekstrak cair, lebih tinggi sekitar $10 \%$ bila dibandingkan dengan tanaman kontrol yang tidak diperlakukan dengan ekstrak cair Sargassum aquifolium. Fenomena yang relatif sama juga terjadi pada tanaman mentimun yang di medianya diberikan ekstrak padat Sargassum aquifolium. Tanaman yang di medianya diberikan 5\% ekstrak padat secara signifikan lebih tinggi sekitar $13,3 \%$ bila dibandingkan dengan tanaman kontrol yang tidak diberikan ekstrak padat (Gambar 3).

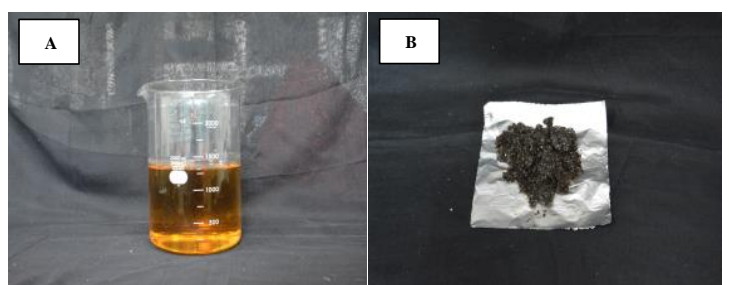

Gambar 2. (A) Ekstrak cair Sargassum Aquifolium

(B) Ekstrak padat Sargassum Aquifolium

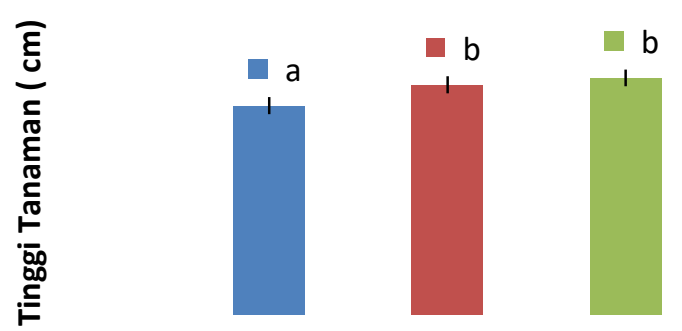

\section{Perlakuan}

Gambar 3. Pengaruh ekstrak cair dan padat Sargassum aquifolium terhadap tinggi tanaman (cm) tanaman mentimun. Nilai rata-rata yang diikuti huruf berbeda menunjukkan beda nyata pada analisis t-test $5 \%$.

Selain mempengaruhi tinggi tanaman, penyemprotan ekstrak cair dan pemberian ekstrak padat pada media tanah, juga mempengaruhi jumlah cabang tanaman mentimun (Gambar 4). Penyemprotan 10\% ekstrak cair Sargassum aquifolium seminggu sekali pada masa vegetatif tanaman mentimun mempengaruhi secara signifikan jumlah cabang tanaman mentimun. Tanaman mentimun yang disemprotkan esktrak cair alga memiliki jumlah cabang sekitar $27 \%$ lebih banyak dibandingkan dengan tanaman mentimun yang tidak disemprotkan dengan ekstrak cair alga. Selain itu, pemberian ekstrak padat Sargassum aquifolium pada media tanaman mentimun mempengaruhi secara signifikan jumlah cabang tanaman mentimun, sekitar $48,7 \%$ lebih banyak jumlah cabang bila dibandingkan dengan tanaman kontrol (Gambar 4). Jumlah cabang ini, bahkan secara signifikan lebih tinggi bila dibandingkan dengan jumlah cabang tanaman mentimun yang disemprotkan dengan $10 \%$ ekstrak cair, sekitar $17 \%$ lebih banyak cabang.

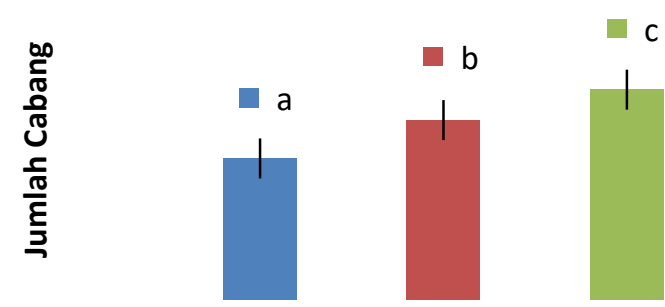

\section{Perlakuan}

Gambar 4. Pengaruh ekstrak cair dan padat Sargassum aquifolium terhadap jumlah cabang tanaman mentimun. Nilai rata-rata yang diikuti huruf berbeda menunjukkan beda nyata pada analisis t-test $5 \%$.

Mengingat ekstrak cair dan ekstrak padat Sargassum aquifolium meningkatkan secara signifikan tinggi tanaman da jumlah cabang, maka ekstrak tersebut juga mempengaruhi berat kering tunas (shoot) sebagaimana ditunjukkan pada gambar 5. Penyemprotan $10 \%$ ekstrak cair alga meningkatkan secara signifikan berat kering tunas, sekitar $42,9 \%$ lebih berat dibandingkan dengan tanaman mentimun yang tidak disemprot dengan ekstrak cair alga. Fenomena yang sama juga ditemukan saat tanaman diberikan ekstrak padat di media, secara signifikan mempengaruhi berat tunas, sekitar 78,6\% lebih berat dibandingkan dengan tanaman mentimun yang tidak diberikan ekstrak padat pada media. Nilai tersebut secara signikan berbeda dengan berat tunas tanaman yang disemprot dengan ekstrak cair, sekitar 25\% lebih tinggi tanaman yang diberikan ekstrak padat di media tanah, dibandingkan dengan tanaman yang diberikan ekstrak cair. 

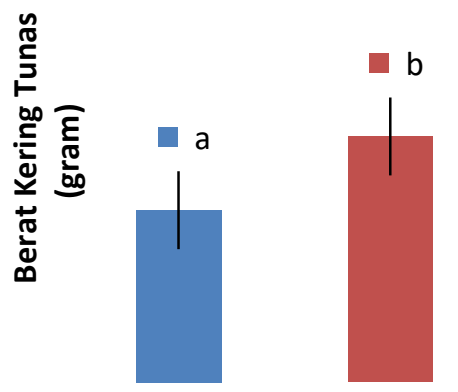

Perlakuan

Gambar 5. Pengaruh ekstrak cair dan padat Sargassum aquifolium terhadap berat kering tunas (shoot) tanaman mentimun. Nilai rata-rata yang diikuti huruf berbeda menunjukkan beda nyata pada analisis t-test 5\%.

Berbeda dengan pengaruh ekstrak pada berat kering tunas (shoot), pemberian ekstrak cair dan padat tidak secara signifikan mempengaruhi berat kering akar (Gambar 6). Selain itu, bila dibandingkan pengaruh ekstrak cair dan ekstrak padat, juga tidak secara signifikan berat kering akar.

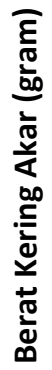
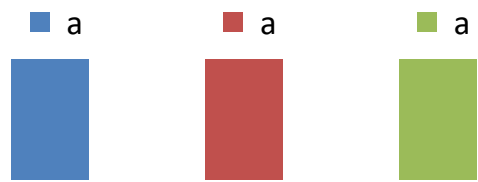

\section{Perlakuan}

Gambar 6. Pengaruh ekstrak cair dan padat Sargassum aquifolium terhadap berat kering akar (root) tanaman mentimun. Nilai rata-rata yang diikuti huruf berbeda menunjukkan beda nyata pada analisis t-test $5 \%$.

Pengaruh ekstrak cair dan padat terhadap hasil tanaman mentimun

Pengaruh esktrak cair dan ekstrak padat terhadap parameter hasil seperti perbungaan, jumlah buah dan berat buat per tanaman, masing-masing ditunjukkan pada gambar 7, 8, dan 9. Data pada gambar 7 menunjukkan bahwa pemberian ekstrak cair secara signifikan mempengaruhi jumlah buah pertanaman. Tanaman mentimun yang disemprotkan dengan $10 \%$ ekstrak cair Sargassum aquifolium secara signifikan menghasilkan jumlah buah per tanaman yang lebih banyak, sekitar $141,3 \%$ lebih banyaak dibandingkan dengan tanaman mentimun yang tidak disemprot dengan $10 \%$ ekstrak cair.
Pada gambar 9 menunjukan perbedaan perbungaan dan hasil dari masing-masing perlakuan yaitu kontrol, pemberian ekstrak cair dan ekstrak padat Sargassum aquifolium.

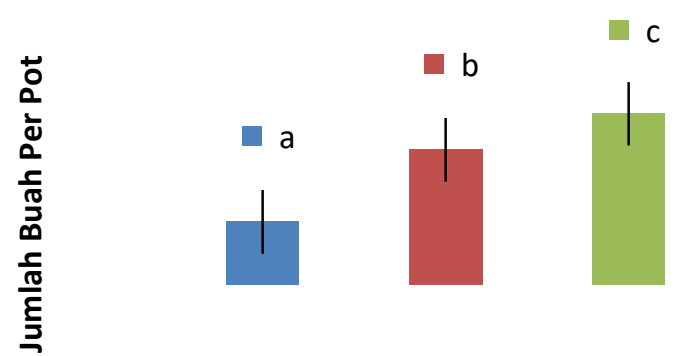

\section{Perlakuan}

Gambar 7. Pengaruh ekstrak cair dan padat Sargassum aquifolium terhadap jumlah buah per tanaman mentimun. Nilai rata-rata yang diikuti huruf berbeda menunjukkan beda nyata pada analisis t-test $5 \%$.

Fenomena yang sama juga ditunjukkan saat tanaman mentimun diberikan 5\% ekstrak padat pada media tanam, sekitar $171,4 \%$ yang secara signifikan lebih banyak dibandingkan dengan tanaman kontrol. Jumlah buah terebut secara signifikan lebih banyak jumlah buahnya sekitar $26,7 \%$ bila dibandingkan dengan tanaman mentimun yang disemprot dengan esktrak cair Sargassum aquifolium.

Ekstrak cair dan padat Sargassum aquifolium juga secara signifikan mempengaruhi berat buat per tanaman (Gambar 8).
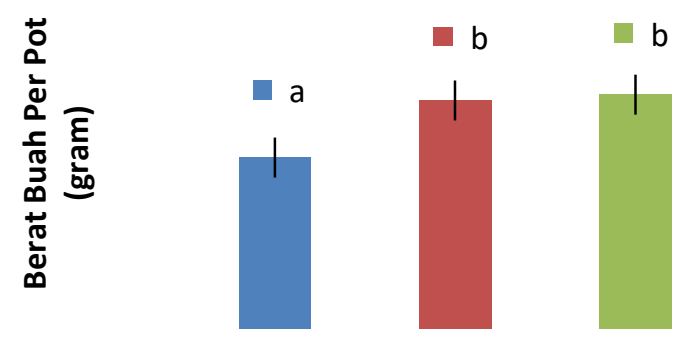

\section{Perlakuan}

Gambar 8. Pengaruh ekstrak cair dan padat Sargassum aquifolium terhadap berat buah per tanaman mentimun. Nilai rata-rata yang diikuti huruf berbeda menunjukkan beda nyata pada analisis t-test $5 \%$. 


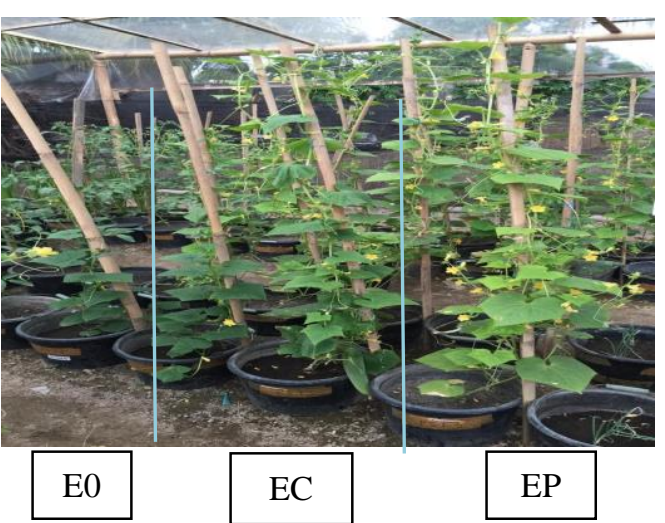

Gambar 9. Pengaruh ekstrak cair dan padat Sargassum aquifolium terhadap pembungaan dan hasil tanaman mentimun. E0 (Kontrol), EC (Ekstrak Cair), EP (Ekstrak Padat).

Ekstrak cair alga secara signifikan mempengaruhi berat buah per tanaman, sekitar 33,3\% lebih berat bila dibandingkan dengan tanaman kontrol. Fenomena serupa juga terjadi saat tanaman diberikan esktark padat pada media tanam, secara signifikan juga mempengaruhi berat buah per tanaman, sekitar 36,7\% lebih berat buahnya bila dibandingkan dengan tanaman kontrol. Meskipun demikian, tidak ada pengaruh yang signifikan antara pemberikan ekstrak cair dan ekstrak padat terhadap berat buah per tanaman.

\section{Pembahasan}

\section{Analisis Kadar Hormon Tumbuh Pada Ekstrak Cair}

Hasil penelitian menunjukkan bahwa esktark cair Sargassum aquifolium mengandung growth hormon 2,4D dan kinetin dengan kadar yang cukup untuk merangsang pertumbuhan dan produksi tanaman (Tabel 1). Mengigat dalam banyak literatur difahami bahwa 2,4D termasuk kelompok auksin yang berperan dalam merangsang pembelahan sel meristematik pada ujung batang dan ujung akar, sedangkan kinetin diketahui memacu pembelahan inti sel (Raven et al., 1992; Salisbury dan Ross, 1995; Teiz and Zeiger, 1998; Buchanan et al., 2000; Zodape et al., 2001; Godlewska et al., 2016), maka penyemprotan ekstrak cair alga tersebut pada organ vegetatif tanaman mentimun akan terjadi pemacuan pembelahan inti sel dan pembelahan sel pada bagian meristematik dan bagian lateral. Akibat pembelahan sel terssebut, maka tanaman mentimun menjadi semakin tinggi dan jumlah cabangnya menjadi bertambah, sebagaimana yang ditunjukkan pada gambar 3 dan 4.
Keberadaan hormon pertumbuhan 2,4-D dan kinetin pada ekstrak cair Sargassum aquifolium (Tabel 1), dan juga hormon pertumbuhan lainnya, seperti gibberellin, NAA dan IAA pada ekstrak cair sepesies rumput laut lainnya, maka beberapa peneliti sebelumnya melaporkan esktrak cair rumput laut merangsang beberapa fase pertumbuhan tanaman, mulai dri fase perkecambahan, pembibitan, pertumbuhan vegetatif dan pertumbuhan generatif. Rangkuman dari beberapa literatur mendokumentasikan bahwa hormon pertumbuhan seperti gibberellin, IAA dan NAA, berperan sebagai transduksi signal untuk memulai kerja enzim katalitik, seperti protease, amilase dan lipase pada bijibijian yang sedang berkecambah (Raven et al., 1992; Salisbury dan Ross, 1995; Teiz dan Zeiger, 1998; Buchanan et al., 2000).

Mengingat ekstrak cair Sargassum aquifolium mengandung hormon tumbuh 2,4-D dan kinetin (Tabel 1), dan beberapa spesies rumput laut lainnya mengandung hormon pertumbuhan lainnya (Zodapr, 2001), maka pemberian ekstrak cair rumput laut memacu perkecambahan biji beberapa tanaman sayuran (Rao dan Chatterjee, 2014), pembibitan tanaman Vigna mungo L. (Kalaivanam dan Venkatesalu, 2012), dan tanaman tomat (Hermandez-Herrera, 2013), pertumbuhan vegetatif beberapa spesies tanaman. Karena ekstrak cair Sargassum aquifolium meningkatkan tinggi tanaman Gambar 3) dan jumlah cabang (Gambar 4), maka pemberian ekstrak cair akhirnya meningkatkan berat kering tunas (shoot) tanaman mentimun (Gambar 5), pembungaan dan hasil tanaman mentimun (gambar 9).

\section{Pengaruh Ekstrak Cair dan Padat Terhadap Tanaman Mentimun}

Meskipun demikian, pemberian esktrak cair tidak mempengaruhi berat kering akar secara signifikan. Hal ini disebabkan karena tatkala pertumbuhan tanaman normal yang ditunjukkan oleh rasio berat kering tunas/berat kering akar $>1$, maka pertumbuhan diprioritaskan pada bagian tunas, bukan pada bagian akar. Sebaliknya, bila tanaman tumbuh dalam keadaan tercekam (stress) yang ditunjukkan oleh rasio berat kering tunas/berat kering akar <1, maka tanaman akan memperioritaskan pertumbuhan akar. Argumentasi itulah yang menjadi alasan, kenapa pemberian ekstrak cair pada kondisi tersebut hanya mempengaruhi pertumbuhan tunas, tetapi tidak mempengaruhi pertumbuhan akar.

Hormon pertumbuhan pada ekstrak cair alga (Tabel 1) tidak hanya mempengaruhi pembelahan sel dan pertumbuhan secara langsung, tetapi juga memacu serapan unsur hara oleh akar dari dalam tanah, fotosintesis, pertumbuhan (Gambar 3, 4 dan 5), dan juga translokasi dan penimbunan makromolekul pada buah. Akibatnya, tanaman mentimun yang disemprotkan 
dengan ekstrak cair Sargassum aquifolium juga meningkatkan jumlah buah (Gambar 7) dan berat buah (Gambar 8) per tanaman. Fenomena serupa dilaporkan peneliti sebelumnya pada tanaman belinjo, tomat dan lombok (Raoo dan Chatterjee, 2014)

Esktrak padat Sargassum aquifolium diketahui mengandung elemen essensial dengan konsentrasi relatif normal untuk elemen $\mathrm{N}, \mathrm{P}, \mathrm{K}, \mathrm{Ca}$ dan Mn. Namun demikian ekstrak ini mengandung elemen $\mathrm{Fe}$ dengan kadar yang signifikan (Tabel 2). Karena itu, pemberian ekstrak padat pada media tanam akan meningkatkan ketersediaan unsur hara di dalam tanah, memacu serapan, fotosintesis, pertumbuhan dan produksi tanaman serta perbungaan dan hasil dari tanaman mentimun (Gambar 3, 4, 5, 6, 7, 8 dan 9). Selain itu, kebedaan Fe dengan kadar yang cukup tinggi, memacu serapan Fe ke tanaman, sintesis klorofil, fotosintesis, pertumbuhan, yang pada akhirnya meningkatkan produktivitas tanaman mentimun, sebagaimana didokumentasikan pada literatur (Buchanan et al., 2000). Atas dasar argumentasi ilmiah itu, maka pemberian ekstrak cair dan padat rumput laut dapat memacu pertumbuhan beberapa sepesies tanaman, seperti tanaman buncis (Sivasankari et al., 2005), tanaman jagung (Safinaz dan Ragaa, 2013) dan tanaman bunga matahari (Majed et al., 2015).

Selain itu, ekstrak cair Hypnea musciformis dan Gracilaria textorii juga dilaporkan mempengaruhi produktivitas tanaman belinjo, tomat dan lombok (Raoo dan Chatterjee, 2014). Peneliti lain juga melaporkan bahwa ekstrak padat mengandung elemen essensial (Godlewska et al., 2016), maka beberapa pupuk organik yang mengandung ekstrak padat (fellet) rumput laut dapat meningkatkan produksi tanaman sayur-sayuran (Li et al., 2017), tanaman kedelai (Kocira et al., 2018), tanaman padi (Sunarpi et al., 2018) dan juga produksi tanaman mentimun pada artikel ini (Gambar 7 dan 8).

Hasil penelitian ini memberikan indikasi bahwa ekstrak cair Sargassum aquifolium dapat dikembangkan sebagai "biostimulan" organik yang dapat merangsang penyerapan unsur hara oleh akar tanaman, fotosintesi, pertumbuhan dan hasil tanaman. Selain itu, ekstrak padat alga ini dapat dikembangkan sebagai "biofertilizer" organik yang diaplikasikan pada media tanah, akan meningkatkan ketersediaan mineral di dalam tanah, memacu serapan mineral, pertumbuhan dan produksi tanaman. Bila hal ini dikembangkan menjadi industri, maka akan tersedia pupuk murah yang ramah lingkungan, dan rumput laut Sargassum aquifolium yang saat ini merupakan rumput laut alam dan tidak memiliki nilai ekonomi, akan menjadi rumput laut yang memiliki nilai ekonomi dan meningkatkan pendapatan masyarakat pesisir di sekitarnya.

\section{Kesimpulan}

Berdasarkan hasil dan pembahasan penelitian yang dipaparkan di atas, maka disimpulkan bahwa ekstrak cair Sargassum aquifolium mengandung hormon 2,4-D dan kinetin yang merangsang serapan unsur hara, fotosintesis, pertumbuhan dan produksi tanaman mentimun. Selain itu, ekstrak padat Sargassum aquifolium mengandung elemen essensial yang dapat dapat meningkatkan ketersediaan unsur hara di dalam tanah, meacu serapan unsur hara, fotosintesis, pertumbuhan dan produksi tanaman mentimun.

\section{Ucapan Terima Kasih}

Ucapan terima kasih disampaikan kepada Kementrian Riset dan Tekonologi yang telah mendanai Penelitian Terapan pada tahun anggaran 2019. Selain itu, author juga mengucapkan terima kasih kepada Pak Bahrain yang telah memberikan bantuan dalam perawatan tanaman mentimun di rumah plastik Jatisela, Kabupaten Lombok Barat, Provinsi Nusa Tenggara Barat.

\section{Daftar Pustaka}

Alburquerque, N., Lydia, F., Mohamed, F., Maria, DN., Jaime, B., Juan, M. \& Lorenzo, B. (2018). 'Towards the Valorization of the invasive seaweeds Caulerpa cylindracea and Asparagopsis taxiformis in the Mediterranean Sea: Applications for in vitro Plant Regeneration and Crop Protection', Journal of Applied Phycology.

Alicja Pohl, Andrzej Kalisz \& Agnieszka Sękara (2019). Seaweed Extracts' Multifactorial Action: Influence on Physiological and Biochemical Status of Solanaceae Plants', Acta Agrobotanica, vol. 1, no. 72, pp. 1- 11.

Altındal, D (2019). 'Effects Of Seaweed Extract (SE) Applications on Seed Germination Characteristics of Wheat in Salinity Conditions', International Journal of Agriculture, Forestry and Life Sciences, 3 (1) : 115- 120.

Anderson J.W. \& Berdall J. (1991). Molecular Activities of Plant Cells. Blackwell Scientific Publications. London. 384p.

Andrea, E, Ornella, F, Anna, T, Michela, S, Diego, P \& Serenella, N. (2018). 'Evaluation of Seaweed Extracts From Laminaria and Ascophyllum nodosum spp. as Biostimulants in Zea mays L. Using a Combination of Chemical, Biochemical and Morphological 
Approaches', $\quad$ Frontiers in Plant Science, 9 (428) : 1-13.

Anggadiredja, J.T., Zatnika, A., Purwoto, H. \& Istini, S. (2010). Rumput Laut: pembudidayaan, Pengolahan dan pemasaran komoditas perikanan potensial. Penebar swadaya. Jakarta.

Buchanan B.B., Gruissem W. \& Jones R.L. (2000). Biochemistry and Molecular Biology of Plants. American Society of Plant Physiologist. USA.1367p.

Chbani A, Majed S., Mawlawi H. \& Kammoun M., (2015). The use of seaweed as biofertilizer: Does it influence proline and chlorophyll in plants tested? Arabian Journal of Medicinal and Aromatic plants. 1(1): 67-77.

Chbani, A, Majed, S, Mawlawi, H \& Kammoun, M. (2015). 'The Use of Seaweed as a Biofertilizer : Does it Ilnfluence Proline and Chlorohyll Concentration in Plants Treate?', Arabian Journal of Medical and Aromatic Plants, 1 (1) : 67-77.

Chojnacka, K., Saeid A., Witkowska, Z. \& Tuhy L. (2012). Biologically active compounds in seaweeds extract-the prospects for the application. The Open Conference Proceedings Journal. 3(1): 20-28.

Crouch IJ \& Van Staden J. (1993). Evidence of the presence of plant growth regulators in commercial seaweed product. Departement of Botany, University of Natal, RSA.

Dewi, EN, Laras Rianingsih \& Apri, DA (2019). 'The Addition of Different Starters on Characteristics Sargassum sp. Liquid Fertilizer', IOP Conf. Series: Earth and Environmental Science.

Frionia, T, Paolo, S, Sergio, T, Jeffrey, N, Stefano, P, Matteo, G. \& Alberto, P. (2018), 'Effects of a Biostimulant Derived from The Brown Seaweed Ascophyllum nodosum On Ripening Dynamics and Fruit Quality of Grapevines', Scientia Horticulturae, pp. 97-106.

Ghaderiardakani, F, Ellen, C, Deborah, KD, Katherine, T, Neil, SG \& Juliet, CC (2019). 'Effects of Green Seaweed Extracton Arabidopsis Early Development Suggest Roles For Hormone Signalling In Plant Responses Toalgal Fertilisers'. Scientific Reports.
Godlewska K., Michalak I, Tuhy L. \& Chojnacka K., (2016). Plant growth biostimulants based on different methods of seaweed extraction with water. BioMed Research International. 2016:1-11.

Godlewska, K, Izabela, M, Lukasz, T \& Chojnacka, K (2016). 'Plant Growth Biostimulant Based on Different Methods of Seaweed Extraction with Water', Biomed Research International, pp. 111.

Hernandez-Herrera R.M., Santacruz-Ruvalcaba F., RuizLopez M.A., Norrie J. \& Hernandez- Carmona G. (2013). Effect of liquid seaweed extract on growth of tomato seedlings (Solanum lycopersicum L.). $J$ App Physiol.

Kalaivanan, C \& Venkatesalu, V (2012) 'Utilazition of Seaweed Sargassum myriocystum Extracts as a Stimulant of Seedlings of Vigna mungo (L.) Hepper', Spanish Journal of Agriculture Research, 10 (2): 446-470.

Kiseleva, AA, Tarachovskaya, ER \& Shishova, MF (2012). 'Biosynthesis of Phytohormones in Algae', Russian Journal of Plant Physiology, 59 (5): 595610.

Kocira S., Szparaga A., Kocira A., Czerwinska E., Wojtowicz A., Bronowicka-Mielniczuk U. Koszel M. \& Findura P. (2018). Modelling biometric traits, yield and nutritional and antioxidant properties of seeds of three soybean cultivars through the application of biostimulants containing seaweed and amino acids. Fronters in Plant Science, 9: 1-18.

Kocira, S, Agniezka, S, Anna, K, Ewa, C, Agniezka, W, Urszula, BM, Milan, K \& Pavol, F (2018).

'Modelling Biometric Traits, Yield and Nutritional and Antioxidant Properties of Seeds of Three Soybean Cultivars Through the Application of Biostimulant Containing Seaweed and Amino Acid', Frontiers in Plants Science, 9 (388): 1-18.

Layek J, Anup, D, Ramkrushna, G I, Dibyendu , S, Arup, G, Sudhakar, T Z, Rattan, L, Gulab, SY, Azad, SP, Shishomvanao, N \& Ram , SM (2017). 'Seaweed Extract as Organic Bio-Stimulant Improves Productivity and Quality of Rice in Eastern Himalayas', Journal Appl Phycol.

Li S., L J., Zhang B., Li D, Li G \& Li Y, (2017). Effect of different organic fertilizers application on growth 
and environmental risk of nitrate under a vegetable field. Scientific report, 7:1-9.

Lucia, TMM, Angela, CMG, Luz, EMC \& Angélica, RD (2019). Effect of Seaweed Liquid Extracts on the Internode Variation of Lens esculenta, Seedlings, 8 (1): $1-5$.

Polo J. \& Mata P. (2018). Evaluation of biostimulant (pepton) based in enzymatic hydrolyzed animal protein in comparison to seaweed extracts on root development, vegetative growth, flowering and yield of gold cherry tomatoes grown under low stress ambient field conditions. Frontiers in Plant Science. 8:1-8.

Rao, GMN \& Reshmi, C (2014). 'Effect Seaweed Liquid Fertilizer from Gracilia textorii and Hypnea musciformis on Seed Germination and Productivity of Some Vegetable Crops', Universal Journal of Plant Science, 2 (7): 115-120.

Raven P.H., Evert R.F. \& Eichhorn S.E. (1992). Biology of Plants. Fifth Edition. Worth Publishers, USA.791p.

Rosalba, MHH, Fernando, SR, Mario, ARL, Jeffrey, N \& Gustavo, HC (2013). 'Effect of Liquid Seaweed Extract on Growth of Tomato Seedling (Solanum lycopersicum L), J Appl Phycol.

Safinaz, AF \& Raga, AH (2013). 'Effect of Some Red Marine Algae as Biofertilizers on Growth of Maizr (Zea mays L.) Plant', International Food Research Journal, 20 (4):1629-1632.

Salisbury F.B. \& Ross C.W. (1991). Plant Physiology. Fourth Edition. Wadsworth Publishing Company. Belmonth. California.681p.

Shuyan, L, Jijin, L, Bangxi, Z, Danyang, L, Guoxue, L \& Yangyang, L (2017). 'Effect of Different Organic Fertilizers Application on Growth and Enviromental Risk of Nitrate Under a Vegetable Field', Scientific Reports, 7 (1792): 1-9.

Sivasankari S., Venkatesalu V., Anantharaj M. \& Chandrasekaran M. (2005). Effect of seaweed extracts on the growth and biochemical constituents of Vignasinensis. Bioresource Technology. 97 (2006): 1745-1751.

Sunarpi \& J.W. Anderson (1995). Mobilization of Sulphur in Soybean Cotyledons during
Germination. Physiologia Plantarum, 94(1):143150 .

Tarachovskaya, ER, Maslov, YU \& Shishova, MF (2007). 'Phytohormones in Algae', Russian Journal of Plant Physiology, 54 (2):163-170.

Tartil, Emam, M, Hosni, AM, Ibrahim, AK \& Hewidy M. (2016). 'Response of Pot Marigold (Calendula officinalis L.) to Different Application Methods and Concentrations of Seaweed Extract', Journal Agriculture Science, 24 (2): 581-591.

Teiz L. \& Zeiger E. (1998). Plant Physiology. Second Edition. Sinauer Associates, Inc., Publishers. Sunderland, Masschusetts. 792 p.

Uthirapandi, V, Selvam, S, Ponnerulan, B, Saminathan, E, Subramanian, SR, Narayanan, V \& Durairaj, K (2018). 'Biofertilizer Potential of Seaweed Liquid Extract of Marine Macro Algae on Growth and Biochemical Parameters of Ocium sanctum', Journal Pharmacognosy and Phytochemestry, 7 (3): 3528-3532.

Uun Sumpena (2001). Budidaya Mentimun Intensif. Penebar swadaya. Jakarta.

Zodape, ST (2001). 'Seaweeds as a Biofertilizer', Journal of Science \& Industrial Research, 60: 378-382 pp. 